\title{
CUMULATIVE AUTHOR INDEX
}

All authors published so far in the current volume are listed alphabetically with the issue and page numbers following the dash. A cumulative author and subject index covering each volume is published annually. An (E) after the page number indicates Erratum.

Abosede, Olufunso - (1) 55

Allwood, A. C. - (2) 162

Amaya, Sandra L. - (4) 315

Arias, L. - (2) 88

Babor, Martin - (3) 242

Benredouane, R. - (3) 209

Bernasconi, Andrea - (1) 11

Bih, L. - (2) 134

Black, D. R. - (3) 202

Blanton, J. R. - (2) 88, 156

Blanton, T. N. - (2) 88, 156

Blanton, Thomas N. - (1) 44, 70, 72;

(2) 166,178 ; (3) 229; (4) 298, 310, 319,330

Boudaren, C. - (3) 209

Brown, C. M. - (3) 202

Brown, D. W. - (2) 141

Camargo, H. A. - (1) 66

Castellanos, N. J. - (1) 66

Cavallo, Giovanni - (4) 270

Chen, Xiaolin - (4) 306

Chen, Zhengwei - (3) 195

Chufarov, A. Y. - (3) 216

Chufarov, A.Yu. - (3) 246

Clausen, B. - (2) 141

Cline, J. P. - (3) 202

Cui, Wei - (3) 195

de Lima Batista, Anderson Márcio -

(1) 21

Delgado, Gerzon E. - (3) 237

Diwanji, S. P. - (4) 279

Du, Qiao Hong - (2) 176

Echavarría, Adriana - (4) 315

El Hachmi, Abdelhadi - (2) 134

Elaamrani, M.A. - (2) 134

Elam, W. T. - (2) 162

Ermakova, L.V. - (3) 246

Etter, Martin - (1) 62

Faber, J. - (4) 336E

Fan, S.-H. - (1) 38

Fawcett, T. G. - (2) 88, 156

Fernandes, José A. - (1) 55

Filliben, J. J. - (3) 202

Flannery, D. T. - (2) 162
Galli, Simona - (1) 55

Gindhart, Amy M. - (1) 44, 70, 72;

(2) 166,178 ; (3) 229 ; (4) 298 , $310,319,330$

Gray III, G. T. - (2) 141

Gu, J.-N. - (1) 38

Guo, Daoyou - (3) 195

Guo, Jiangang - (3) 190

Guo, Shuang - (2) 115

Haloui, R. - (2) 134

Hattan, Daiki - (2) 80, 108, 121

He, Bing - (2) 172

He, Bob B. - (2) 147

He, Meng - (1) 4

Heaney, Peter J. - (4) 287

Heirwegh, C. M. - (2) 162

Henao, J. A. - (1) 66; (3) 225

Henins, A. - (3) 202

Hou, Quan - (2) 176

Huang, Yuanqi - (3) 195

Huber, Stepan - (3) 242

Ida, Takashi - (2) 80, 108, 121

Jian, Jikang - (2) 115

Jurasek, Bronislav - (3) 242

Kabekkodu, S. N. - (2) 156

Kaduk, J. A. - (4) 279

Kaduk, James A. - (1) 44, 49, 70, 72 ; (2) $98,166,178$; (3) 229; (4)

298, 303, 310, 319, 330

Kalainathan, S. (4) 303

Knapp, C. M. - (2) 141

Kouznetsov, V. - (3) 225

Kuchar, Martin - (3) 242

López-Rivera, S. A. - (3) 237

Lapidus, S. H. - (4) 279

Lazor, P. - (2) 134

Lei, Renbo - (2) 115

Li, Degui - (2) 172

Li, Hui - (1) 4; (2) 176; (4) 327

Li, Kunkun - (3) 190

Liang, Liuqing - (2) 172

Liao, Lidong - (4) 327

Liu, Haitao - (2) 115

Lobachevskaja, N. I. - (3) 216, 246
Lu, Tian - (2) 172

Luo, Kun - (2) 172

Ma, F.-F. - (1) 38

Madsen, Ian C. - (1) 26

Manfredy, Luigi - (3) 237

Manoun, Bouchaib - (2) 134

Mao, J.-W. - (1) 38

Martinez, D. T. - (2) 141

Martins, Fátima Itana Chaves

Custódio - (1) 21

Matei, Lidia - (1) 49

Mendenhall, M. H. - (3) 202

Mendenhall, Marcus H. - (4) 266

Miranda, Marcus Aurélio Ribeiro (1) 21

Morilla Santos, Cássio - (1) 21

Murugesan, G. - (4) 303

Nandan, K. R. - (4) 303

Nomura, Katsuhiro - (2) 80, 108, 121

Ono, Shoki - (2) 80, 108, 121

Peterson, Kristina M. - (4) 287

Pinto, J. L. - (3) 225

Post, Jeffrey E. - (4) 287

Qin, Ming - (2) 172

Reid, Joel W. - (1) 49

Ribaud, L. - (4) 279

Rosas, C. C. - (1) 66

Saadoune, I. - (2) 134

Sasaki, José Marcos - (1) 21

Scarlett, Nicola V. Y. - (1) 26

Shao, G.-Q. - (1) 38

Shen, Shijie - (3) 190

Sunzeri, Joseph G. - (3) 229

Suo, Zi Li - (2) 176

Suo, Zili - (4) 306, 327

Suscavage, T. - (2) 88

Takajo, S. - (2) 141

Takatsu, Yoshinobu - (2) 80, 108, 121

Tamraoui, Y. - (2) 134 
Tang, Weihua - (3) 195

Trujillo, C. P. - (2) 141

Tyutyunnik, A. P. - (3) 216, 246

Vázquez de Ágredos Pascual, Maria

Luisa - (4) 270

Velikodnyi, A. A. - (3) 216

Velikodnyi, Yu. A. - (3) 246

Vickers, Martin - (3) 229

Vogel, S. C. - (2) 141

Wang, Qing - (4) 306
Wang, Shufang - (2) 115

Wang, Wan - (4) 327

Wheatley, Austin M. - (1) 44, 70, 72; (3) 229; (4) 298, 319

Whitfield, P. S. - (3) 202

Wong-Ng, W. - (4) 279

Wright, Jonathan - (1) 11

Wu, Jing - (2) 115

Wu, Zhenping - (3) 195

Xie, G.-Z. - (1) 38

Xiong, Xin Nuo - (2) 176
Yan, Hui - (3) 195

Yan, J.-L. - (1) 38

Yoshida, Takehiro - (2) 80, 108, 121

Yuan, Duanduan - (3) 190

Zeng, Xia - (2) 176

Zhang, A.-L. - (1) 38

Zhang, Ze - (1) 4

Zhi, Yusong - (3) 195

Zhu, C. - (1) 38

Zhuravlev, V. D. - (3) 216, 246 
1. Publication Title

Powder Diffraction

4. Issue Frequency

Quarterly March, June, Sept, December

7. Complete Mailing Address of Known Office of Publication (Not printer) (Street, city, county, state, and ZIP+4)

Cambridge University Press

1 Liberty Plaza

New York, NY 10006

8. Complete Mailing Address of Headquarters or General Business Office of Publisher (Not printer)

Cambridge University Press

Edinburgh Building, Cambridge CB2 2RU, England

\begin{tabular}{|c|l}
\hline 2. Publication Number & $\begin{array}{c}\text { S. Filing Date } \\
10 / 1 / 2018\end{array}$ \\
\hline $\begin{array}{c}010-071 \\
4\end{array}$ & $\begin{array}{l}\text { 6. Annual Subscription Price } \\
\$ 472\end{array}$ \\
\hline & $\begin{array}{l}\text { Contact Person } \\
\text { Nina lammatteo }\end{array}$ \\
\cline { 2 - 3 } & $\begin{array}{c}\text { Telephone (Include area code) } \\
2123375004\end{array}$ \\
\hline
\end{tabular}

9. Full Names and Complete Mailing Addresses of Publisher, Editor, and Managing Editor (Do not leave blank)

Publisher (Name and complete mailing address)

Cambridge University Press

1 Liberty Plaza

New York, NY 10006

Editor (Name and complete mailing address)

Camden Hubbard, International Centre for Diffraction Data, 12 Campus Blvd, Newtown Square, PA 19073-3273 USA

Managing Editor (Name and complete mailing address)

10. Owner (Do not leave blank. If the publication is owned by a corporation, give the name and address of the corporation immediately followed by the names and addresses of all stockholders owning or holding 1 percent or more of the total amount of stock. If not owned by a corporation, give the names and addresses of the individual owners. If owned by a partnership or other unincorporated firm, give its name and address as well as those of each individual owner. If the publication is published by a nonprofit organization, give its name and address.)

Full Name

The International Centre for Diffraction Data

Complete Mailing Address

12 Campus Blvd.

Newtown Square, PA 19073-3273

USA

11. Known Bondholders, Mortgagees, and Other Security Holders Owning or Holding 1 Percent or More of Total Amount of Bonds, Mortgages, or Other Securities. If none, check box $\rightarrow$ None

\begin{tabular}{l|l}
\hline Full Name & Complete Mailing Address \\
\hline & \\
\hline & \\
\hline & \\
\hline & \\
\hline
\end{tabular}

12. Tax Status (For completion by nonprofit organizations authorized to mail at nonprofit rates) (Check one)

The purpose, function, and nonprofit status of this organization and the exempt status for federal income tax purposes:

$\square$ Has Not Changed During Preceding 12 Months

$\square$ Has Changed During Preceding 12 Months (Publisher must submit explanation of change with this statement) 


\begin{tabular}{|c|c|c|c|c|}
\hline \multirow{2}{*}{\multicolumn{3}{|c|}{$\begin{array}{l}\text { 13. Publication Title } \\
\text { Powder Diffraction } \\
\text { 15. Extent and Nature of Circulation }\end{array}$}} & \multicolumn{2}{|c|}{$\begin{array}{l}\text { 14. Issue Date for Circulation Data Below } \\
\text { JUNE } 2018\end{array}$} \\
\hline & & & \multirow{2}{*}{\begin{tabular}{|c|}
$\begin{array}{l}\text { Average No. Copies } \\
\text { Each Issue During } \\
\text { Preceding } 12 \text { Months }\end{array}$ \\
374 \\
\end{tabular}} & $\begin{array}{l}\text { No. Copies of Single } \\
\text { Issue Published } \\
\text { Nearest to Filing Date }\end{array}$ \\
\hline \multicolumn{3}{|c|}{ a. Total Number of Copies (Net press run) } & & 459 \\
\hline \multirow{4}{*}{$\begin{array}{l}\text { b. Paid } \\
\text { Circulation } \\
\text { (By Mail } \\
\text { and } \\
\text { Outside } \\
\text { the Mail) }\end{array}$} & (1) & $\begin{array}{l}\text { Mailed Outside-County Paid Subscriptions Stated on PS Form } 3541 \text { (Include paid } \\
\text { distribution above nominal rate, advertiser's proof copies, and exchange copies) }\end{array}$ & 37 & 34 \\
\hline & (2) & $\begin{array}{l}\text { Mailed In-County Paid Subscriptions Stated on PS Form } 3541 \text { (Include paid } \\
\text { distribution above nominal rate, advertiser's proof copies, and exchange copies) }\end{array}$ & 0 & 0 \\
\hline & (3) & $\begin{array}{l}\text { Paid Distribution Outside the Mails Including Sales Through Dealers and Carriers, } \\
\text { Street Vendors, Counter Sales, and Other Paid Distribution Outside USPS }\end{array}$ & 158 & 134 \\
\hline & (4) & $\begin{array}{l}\text { Paid Distribution by Other Classes of Mail Through the USPS } \\
\text { (e.g., First-Class Mailब) }\end{array}$ & 0 & 0 \\
\hline \multicolumn{3}{|c|}{ c. Total Paid Distribution [Sum of 15b (1), (2), (3), and (4)] } & 195 & 168 \\
\hline \multirow{4}{*}{$\begin{array}{l}\text { d. Free or } \\
\text { Nominal } \\
\text { Rate } \\
\text { Distribution } \\
\text { (By Mail } \\
\text { and } \\
\text { Outside } \\
\text { the Mail) }\end{array}$} & (1) & Free or Nominal Rate Outside-County Copies included on PS Form 3541 & 0 & 0 \\
\hline & (2) & Free or Nominal Rate In-County Copies Included on PS Form 3541 & 0 & 0 \\
\hline & (3) & $\begin{array}{l}\text { Free or Nominal Rate Copies Mailed at Other Classes Through the USPS } \\
\text { (e.g., First-Class Mail) }\end{array}$ & 0 & 0 \\
\hline & (4) & Free or Nominal Rate Distribution Outside the Mail (Carriers or other means) & 2 & 2 \\
\hline \multicolumn{3}{|c|}{ e. Total Free or Nominal Rate Distribution (Sum of 15d (1), (2), (3) and (4)) } & 2 & 2 \\
\hline \multicolumn{3}{|c|}{ f. Total Distribution (Sum of $15 \mathrm{c}$ and $15 \mathrm{e}$ ) } & 197 & 170 \\
\hline \multicolumn{3}{|c|}{ g. Copies not Distributed (See Instructions to Publishers \#4 (page \#3)) } & 177 & 289 \\
\hline \multicolumn{3}{|c|}{ h. Total (Sum of $15 f$ and $g$ ) } & 374 & 459 \\
\hline \multicolumn{3}{|c|}{$\begin{array}{l}\text { i. Percent Paid } \\
\text { (15c divided by } 15 f \text { times } 100 \text { ) }\end{array}$} & $98.98 \%$ & $98.82 \%$ \\
\hline \multicolumn{3}{|c|}{ 16. Electronic Copy Circulation } & \begin{tabular}{|l|} 
Average No. Copies \\
Each Issue During \\
Preceding 12 Months
\end{tabular} & $\begin{array}{l}\text { No. Copies of Single } \\
\text { Issue Published } \\
\text { Nearest to Filing Date }\end{array}$ \\
\hline \multicolumn{3}{|c|}{ a. Paid Electronic Copies } & 0 & 0 \\
\hline \multicolumn{3}{|c|}{ b. Total Paid Print Copies (Line 15c) + Paid Electronic Copies (Line 16a) } & 195 & 168 \\
\hline \multicolumn{3}{|c|}{ c. Total Print Distribution (Line 15f) + Paid Electronic Copies (Line 16a) } & 197 & 170 \\
\hline \multicolumn{3}{|c|}{ d. Percent Paid (Both Print \& Electronic Copies) (16b divided by $16 \mathrm{c} \times 100$ ) } & $98.98 \%$ & $98.82 \%$ \\
\hline
\end{tabular}

QI certify that $50 \%$ of all my distributed copies (electronic and print) are paid above a nominal price.

\section{Publication of Statement of Ownership}

If the publication is a general publication, publication of this statement is required. Will be printed

in the December_issue of this publication.

18. Signature and fittle of Editor, Publisher, Business Manager, or Owner
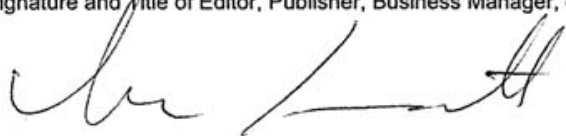

$10 / 1 / 2018$

I certify that all information furnished on this form is true and complete. I understand that anyone who furnishes false or misleading information on this form or who omits material or information requested on the form may be subject to criminal sanctions (including fines and imprisonment) and/or civil sanctions (including civil penalties). 

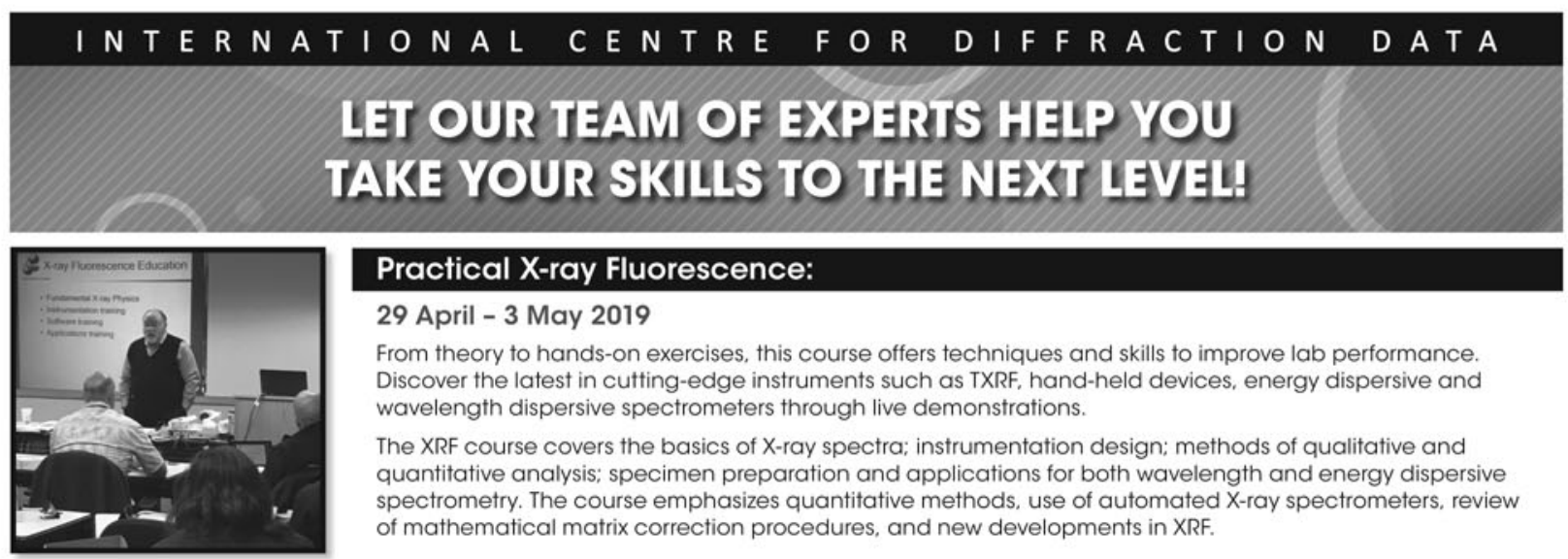

Practical X-ray Fluorescence:

29 April - 3 May 2019

From theory to hands-on exercises, this course offers techniques and skills to improve lab performance. Discover the latest in cutting-edge instruments such as TXRF, hand-held devices, energy dispersive and wavelength dispersive spectrometers through live demonstrations.

The XRF course covers the basics of X-ray spectra; instrumentation design; methods of qualitative and quantitative analysis; specimen preparation and applications for both wavelength and energy dispersive spectrometry. The course emphasizes quantitative methods, use of automated X-ray spectrometers, review of mathematical matrix correction procedures, and new developments in XRF.

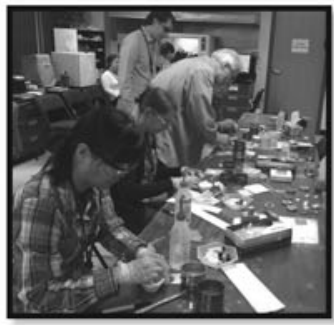

\section{Fundamentals of X-ray Powder Diffraction:}

\section{3 - 7 June 2019}

For the novice with some XRD knowledge or for the experienced with an interest in the theory behind XRD. this clinic offers a strong base for increased lab performance.

The clinic covers instrumentation, specimen preparation, data acquisition and qualitative phase analysis through live demonstrations. It also covers hands-on use of personal computers for demonstration of the latest software including data mining with the Powder Diffraction File (PDF) and use of the powder diffractometer: optical arrangement, factors affecting instrumentation profile width, choice and function of divergence slit, calibration and alignment, detectors, and X-ray optics.

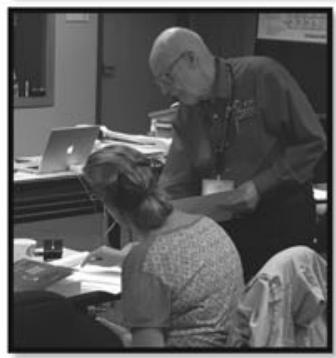

\section{Advanced Methods in X-ray Powder Diffraction:}

\section{0 - 14 June 2019}

For the experienced XRD scientist, this session offers enhanced analysis skills through intense problem solving. as well as an introduction to the Rietveld Method. The course emphasizes computer-based methods of data collection and interpretation, both for qualitative and quantitative phase analysis.

The advanced clinic covers factors affecting $\mathrm{d}$-spacings of crystals, as well as factors affecting diffraction-line intensities; structure-sensitive properties (atomic scattering and structure factors), polarization effects, and multiplicity. Additionally, the clinic covers specimen-sensitive effects (orientation, particle size), measurementsensitive effects (use of peak heights and peak areas), and choice of scanning conditions will also be addressed.

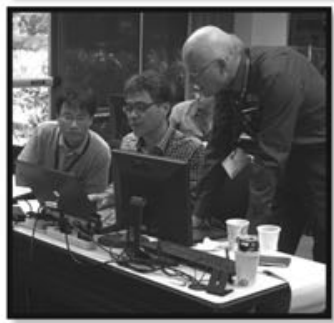

\section{Rietveld Refinement \& Indexing Clinic:}

23 - 27 September 2019

Powder pattern indexing and Rietveld structural refinement techniques are complementary and are often used to completely describe the structure of a material. Successful indexing of a powder pattern is considered strong evidence for phase purity. Indexing is considered a prelude to determining the crystal structure, and permits phase identification by lattice matching techniques. This clinic introduces the theory and formalisms of various indexing methods and structural refinement techniques along with quantitative analysis. One unique aspect of this clinic is the extensive use of computer laboratory problem solving and exercises that teach method development in a hands-on environment.

Please visit the ICDD website for more information.

\section{Register today at WWW.ICDD.COM}

Please note: A minimum of 10 registrants per course is required, otherwise the course will be cancelled and your registration fee will be refunded. You will be notified of a course cancellation no later than two weeks prior to the start of the course.
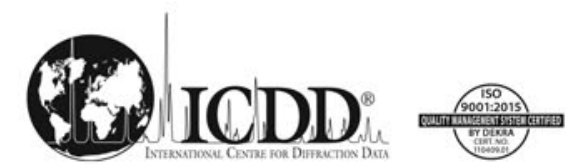

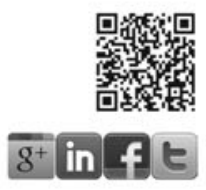

\section{For More Information Contact}

Eileen Jennings, Education Coordinator

Tel: 610.325 .9814 Fax: 610.325 .9823

Email: clinics@icdd.com

Location

ICDD Headquarters, 12 Campus Boulevard

Newtown Square, Pennsylvania 19073-3273 USA

C2018 JCPOS-International Centro for Diffraction Data

ICDO 10/18 
I NTERNATIONAL CENTRE FOR DIFFRACTION DATA

\section{GRANT-IN-AID FUNDS ARE AVAILABLE DO NOT DELAY!}

\section{Submission deadline is 31 January 2019}

Does your research project involve the preparation and characterization of new materials using powder diffraction techniques?

If the answer is YES, then ICDD's Grant Program is the perfect fit for you!

See if you qualify to submit a proposal to ICDD in two simple steps:

Step 1: Submit a sample XRD dataset in .CIF format

Step 2: Submit a powder diffraction pattern of NIST standard reference material, preferably Al203, Aluminum Oxide.

\section{Please email sample patterns to:}

Denise DelCasale

ICDD Grant-in-Aid Coordinator

Delcasale@icdd.com

ICDD for over 75 years has been dedicated to collecting, editing, publishing, and distributing powder diffraction data for the identification of crystalline materials. To assist us in this growth, ICDD has called on researchers from around the world to contribute their experimental data. In return, ICDD supports their efforts by funds provided through our Grant-in-Aid Program.

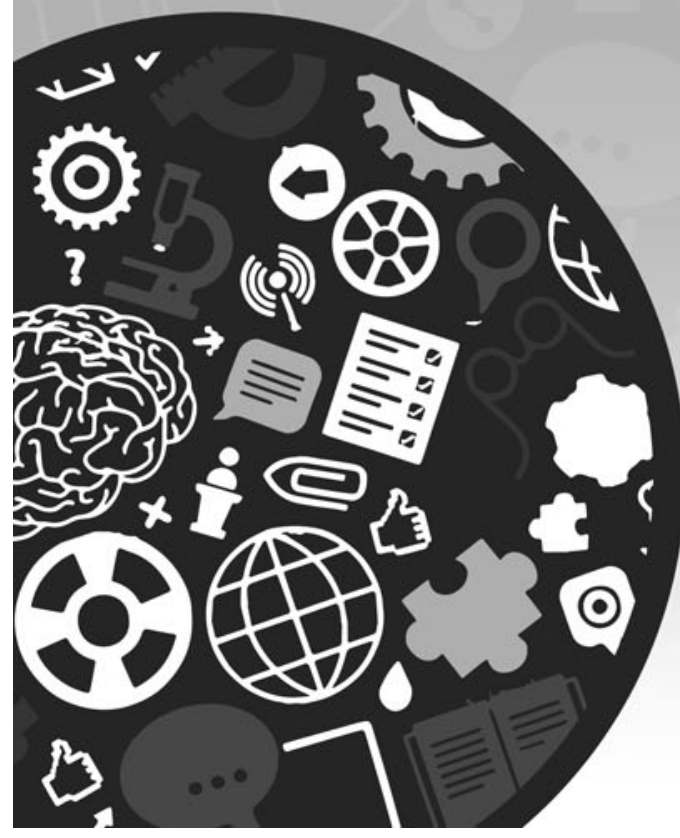

ICDD's approved grantees receive these additional benefits:

- A 50\% price reduction on a PDF-4+ or PDF-4/Organics product

- Financial support to aid current research projects

- Publication of pattern(s) in the Powder Diffraction File ${ }^{T M}$ (PDF ${ }^{\circledR}$ ) once approved by the Editorial Department

- NIST standard alumina powder or alumina plate for instrument calibration

- Access to the list of compounds in the ICDD master database: includes published patterns, as well as patterns in the editorial process

- First-time grantees receive a complimentary one-year subscription to Powder Diffraction Journal 


\section{NTERNATIONAL CENTRE FOR DIFFRACTION DATA}

\section{Diffraction Data You Can Trust}

ICDD databases are the only crystallographic databases in the world with quality marks and quality review processes that are ISO certified.

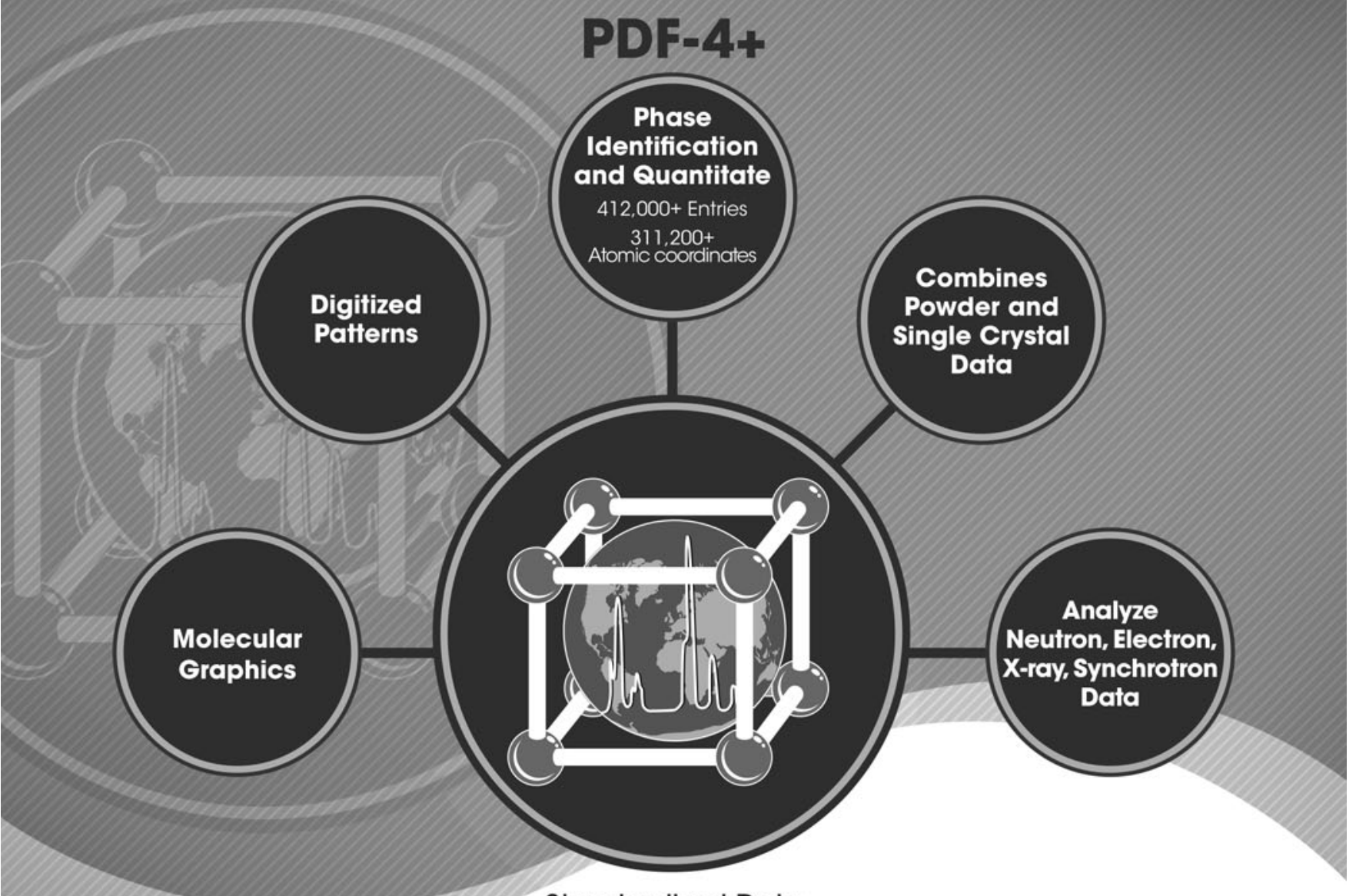

Standardized Data

\section{More Coverage}

All Data Sets Evaluated For Quality

Reviewed, Edited and Corrected Prior To Publication

Targeted For Material Identification and Characterization

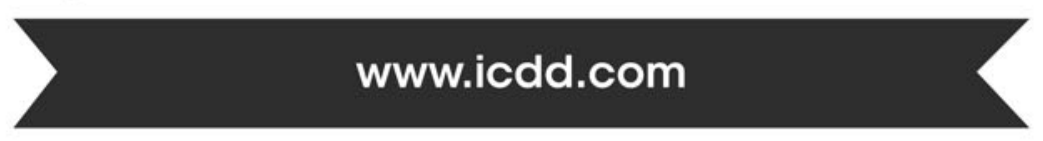


INTERNATIONAL CENTRE FOR DIFFRACTION DATA

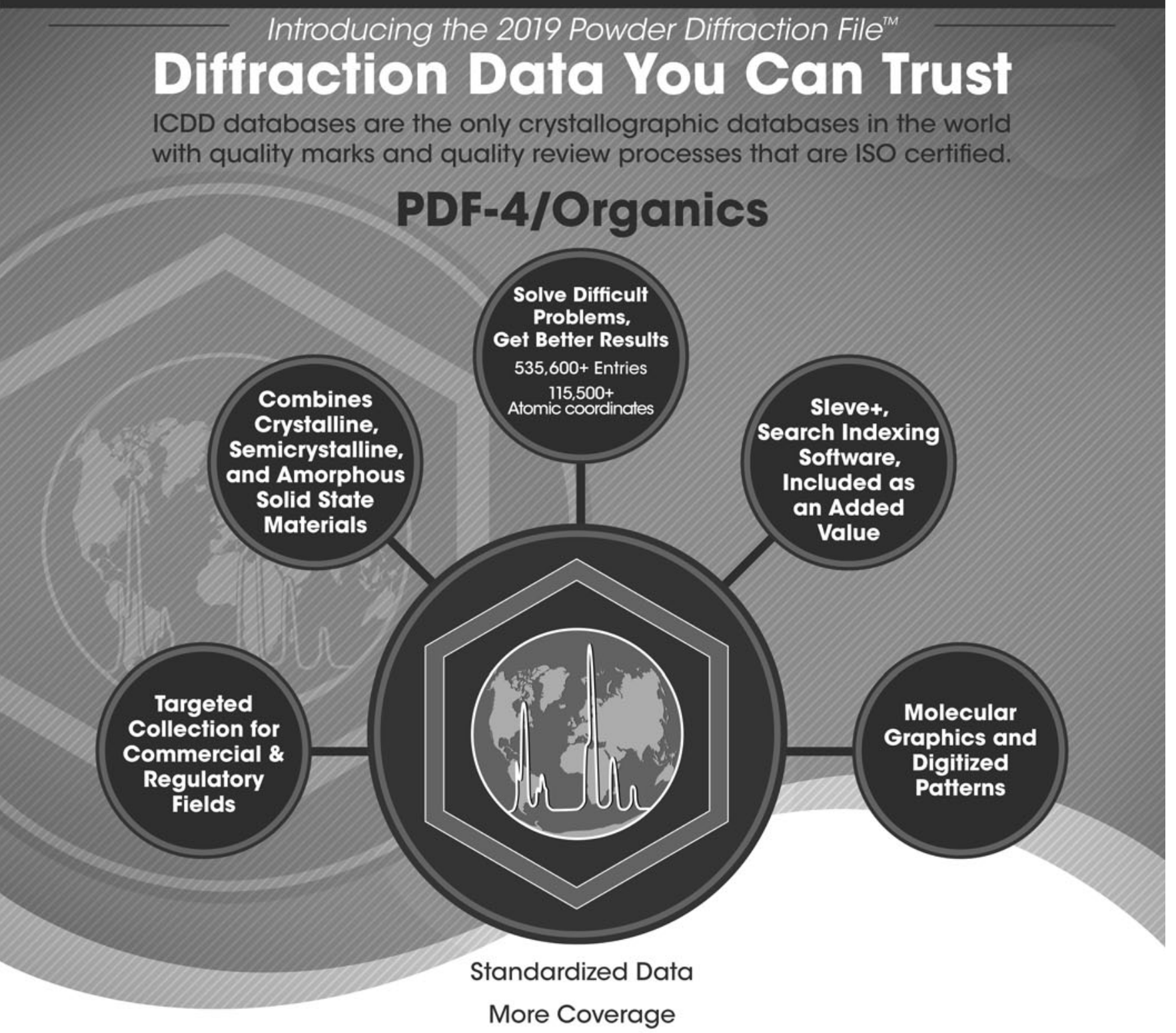

All Data Sets Evaluated For Quality

Reviewed, Edited and Corrected Prior To Publication

Targeted For Material Identification and Characterization

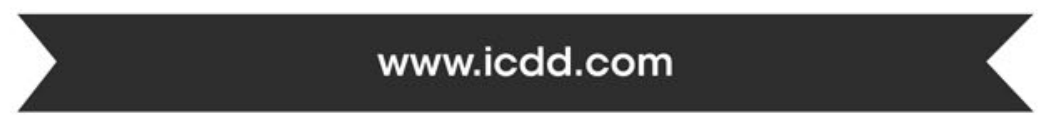


I NTERNATIONAL CENTRE FOR DIFFRACTION DATA

\section{Introducing the 2019 Powder Diffraction File ${ }^{\text {Tm }}$ \\ Diffiraction Data You Can Trust}

ICDD databases are the only crystallographic databases in the world with quality marks and quality review processes that are ISO certified.

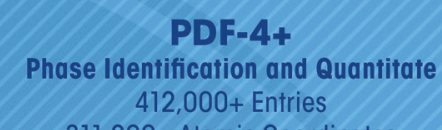

$311,200+$ Atomic Coordinates

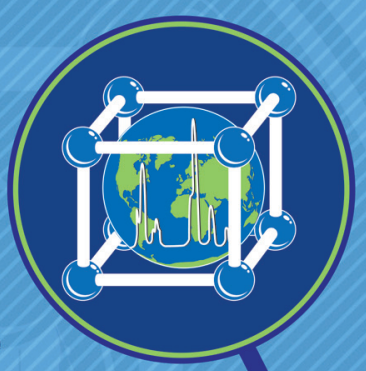

WebPDF $-4+$

Data on the $G 0$

$412,000+$ Entries

$311,200+$ Atomic Coordinates

PDF-2

Phase Identification + Value $304,100+$ Entries

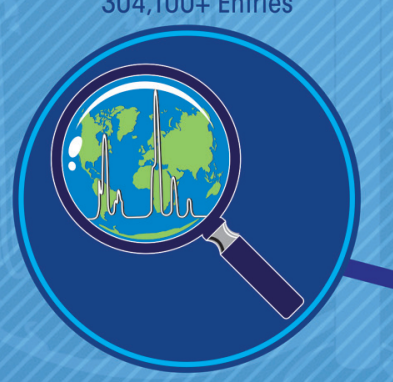

PDF-4/Organics

Solve Difficult Problems, Get Better Results $535,600+$ Entries

$115,500+$ Atomic Coordinates

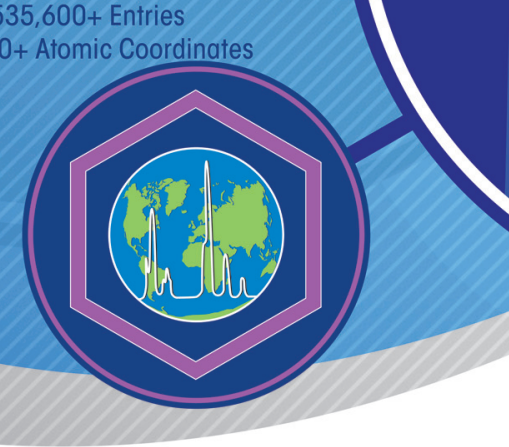

\section{Standardized Data}

\section{Powder} Diffraction File ${ }^{\mathrm{Tm}}$

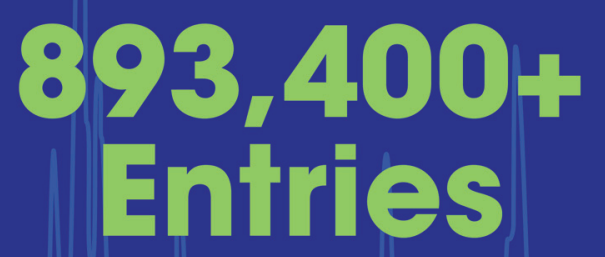

More Coverage

All Data Sets Evaluated For Quality

Reviewed, Edited and Corrected Prior To Publication

Targeted For Material Identification and Characterization

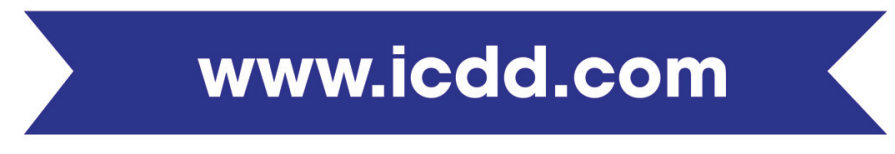

Focused on Identificam

on Identification + Quantitation for Benchtop Users

87,000 + Entries • $61,600+$ Atomic Coordinates

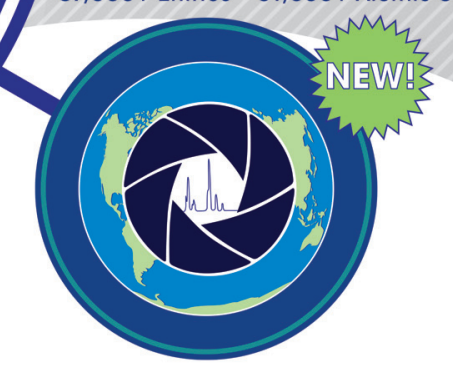

hensive Mineral Collection 46,100+Entries

$37,000+$ Atomic Coordinates 


\section{improve your science}

with the AXRD Theta-Theta Powder Diffractometer
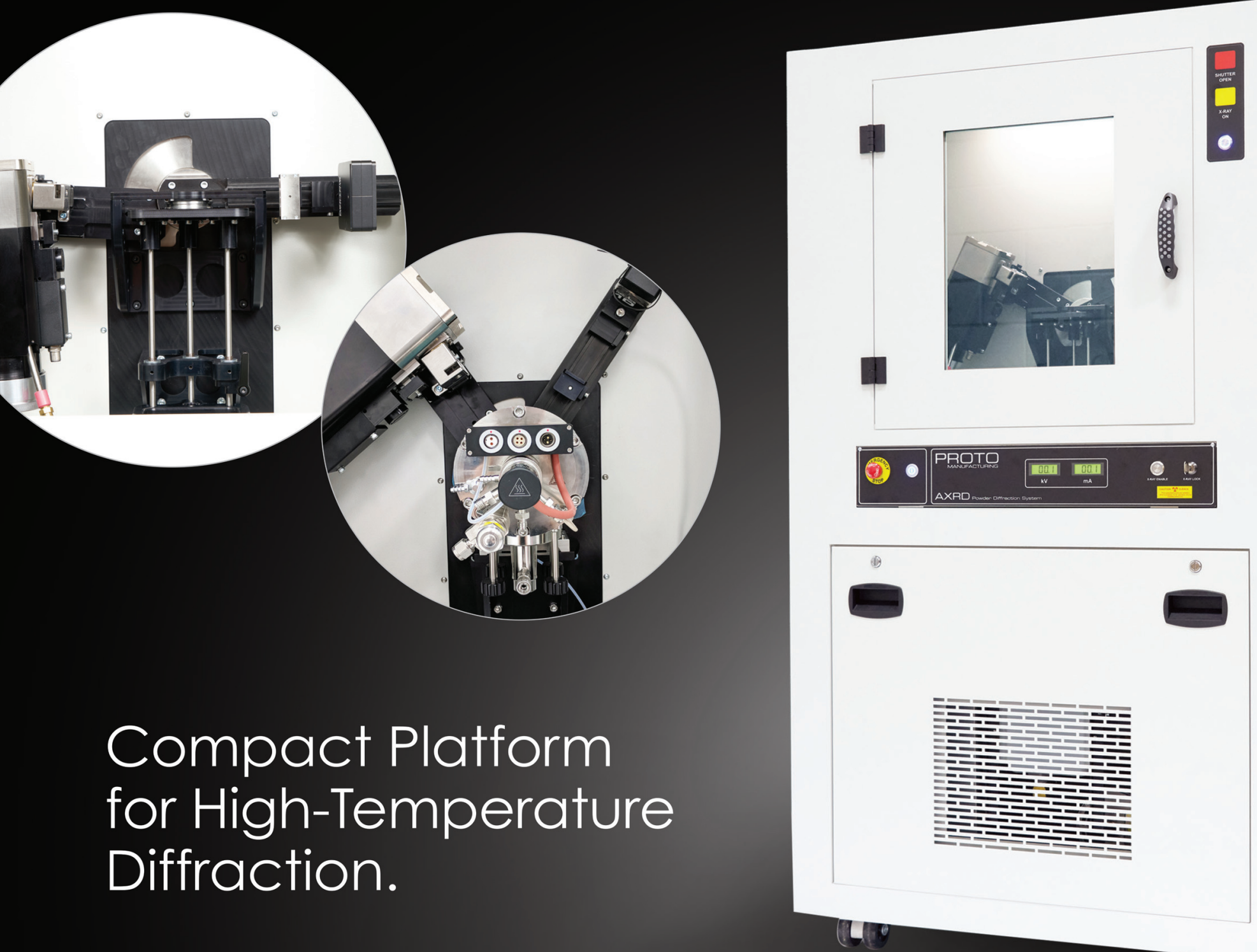

Compact Platform for High-Temperature Diffraction.

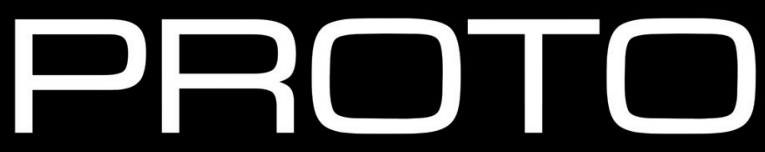

x-ray diffraction systems \& services
For more information and to download our product catalog.

1-734-946-0974 powder@protoxrd.com 